\title{
The effectivity of the new improved Maastricht brace compared with the Boston brace
}

\author{
J Hermus*', M Hulsbosch, C Arts, L Van Rhijn \\ From 8th International Conference on Conservative Management of Spinal Deformities and SOSORT 2011 \\ Annual Meeting \\ Barcelona, Spain. 19-21 May 2011
}

\section{Background}

The brace 2000 was developed to improve the compliance of brace treatment and therefore its results. We further developed the brace 2000 in the Maastricht brace ( $M$ brace) to enhance the effectivity of the brace and its wearing comfort.

\section{Materials and methods}

Pressure measurements were performed in 4 patients wearing the Boston brace and the $M$ brace to understand the efficacy between the two braces without intervariability $[1,2]$.

\section{Results}

The mean primary right thoracic curve was $29^{\circ}$ uncorrected; the mean secondary curve measured $19^{\circ}$. In the Boston brace group the mean primary right thoracic curve was $22^{\circ}$; the mean secondary curve measured $16^{\circ}$. The mean corrective force over the lumbar brace pad in standing position was $382 \mathrm{~N}$; over the thoracic brace pad it was $285 \mathrm{~N}$. In the $\mathrm{M}$ brace group the mean primary right thoracic curve was $20^{\circ}$; the mean secondary curve measured $13^{\circ}$. The mean corrective force over the lumbar brace pad in standing position was $373 \mathrm{~N}$; over the thoracic brace pad it was $311 \mathrm{~N}$. Difference in M-brace and Boston brace was not significant, for the lumbar brace pad: 0.12 , for the thoracic brace pad 0.07 with ANOVA analysis.

\section{Conclusions}

There is a tendency that the $\mathrm{M}$ Brace give a higher pressure comparing to the classic Boston brace with a better correction on the spinal radiograph. Bracing results are directly related to compliance with brace treatment; therefore, optimal results cannot be achieved without the patient's cooperation and family support. Brace mechnisms can be explained and understood by giving more insight about pressure/force measurements in the brace. The Quality of life measured with the SRS 22 and Brace questionnaire was higher in the Brace 2000 than the Boston brace.

Published: 27 January 2012

\section{References}

1. Parent S, Newton PO, Wenger DR: Adolescent idiopathic scoliosis: natural history and long-term treatment effects. Instr Course Lect 2005, 54:529-36, Review.

2. van den Hout JA, van Rhijn LW, van den Munckhof RJ, van Ooy A: Interface corrective force measurements in Boston brace treatment. Eur. Spine J 2002, 11(4):332-5.

doi:10.1186/1748-7161-7-S1-041

Cite this article as: Hermus et al:: The effectivity of the new improved Maastricht brace compared with the Boston brace. Scoliosis 2012 7(Suppl 1):041.
Submit your next manuscript to BioMed Central and take full advantage of:

- Convenient online submission

- Thorough peer review

- No space constraints or color figure charges

- Immediate publication on acceptance

- Inclusion in PubMed, CAS, Scopus and Google Scholar

- Research which is freely available for redistribution
( Biomed Central
Maastricht University Medical Center, Maastricht, The Netherlands 